\title{
A cloud-ozone data product from Aura OMI and MLS satellite measurements
}

\author{
Jerald R. Ziemke ${ }^{1,2}$, Sarah A. Strode ${ }^{2,3}$, Anne R. Douglass ${ }^{2}$, Joanna Joiner ${ }^{2}$, Alexander Vasilkov ${ }^{2,4}$, Luke D. Oman ${ }^{2}$, \\ Junhua Liu ${ }^{2,3}$, Susan E. Strahan ${ }^{2,3}$, Pawan K. Bhartia ${ }^{2}$, and David P. Haffner ${ }^{2,4}$ \\ ${ }^{1}$ Morgan State University, Baltimore, Maryland, USA \\ ${ }^{2}$ NASA Goddard Space Flight Center, Greenbelt, Maryland, USA \\ ${ }^{3}$ Universities Space Research Association, Columbia, Maryland, USA \\ ${ }^{4}$ SSAI, Lanham, Maryland, USA
}

Correspondence to: Jerald R. Ziemke (jerald.r.ziemke@ nasa.gov)

Received: 7 April 2017 - Discussion started: 27 April 2017

Revised: 8 September 2017 - Accepted: 25 September 2017 - Published: 1 November 2017

\begin{abstract}
Ozone within deep convective clouds is controlled by several factors involving photochemical reactions and transport. Gas-phase photochemical reactions and heterogeneous surface chemical reactions involving ice, water particles, and aerosols inside the clouds all contribute to the distribution and net production and loss of ozone. Ozone in clouds is also dependent on convective transport that carries low-troposphere/boundary-layer ozone and ozone precursors upward into the clouds. Characterizing ozone in thick clouds is an important step for quantifying relationships of ozone with tropospheric $\mathrm{H}_{2} \mathrm{O}, \mathrm{OH}$ production, and cloud microphysics/transport properties. Although measuring ozone in deep convective clouds from either aircraft or balloon ozonesondes is largely impossible due to extreme meteorological conditions associated with these clouds, it is possible to estimate ozone in thick clouds using backscattered solar UV radiation measured by satellite instruments. Our study combines Aura Ozone Monitoring Instrument (OMI) and Microwave Limb Sounder (MLS) satellite measurements to generate a new research product of monthly-mean ozone concentrations in deep convective clouds between $30^{\circ} \mathrm{S}$ and $30^{\circ} \mathrm{N}$ for October 2004-April 2016. These measurements represent mean ozone concentration primarily in the upper levels of thick clouds and reveal key features of cloud ozone including: persistent low ozone concentrations in the tropical Pacific of $\sim 10 \mathrm{ppbv}$ or less; concentrations of up to $60 \mathrm{pphv}$ or greater over landmass regions of South America, southern Africa, Australia, and India/east Asia; connections with tropical ENSO events; and intraseasonal/Madden-Julian os-
\end{abstract}

cillation variability. Analysis of OMI aerosol measurements suggests a cause and effect relation between boundary-layer pollution and elevated ozone inside thick clouds over landmass regions including southern Africa and India/east Asia.

\section{Introduction}

Measuring tropospheric ozone in deep convective clouds including convective outflow regions in the mid-to-upper troposphere is important for several reasons. Ozone in the upper troposphere is a major greenhouse gas that contributes to climate forcing. The IPCC 2013 report (e.g., in Hartmann et al., 2014; http://www.ipcc.ch/report/ar5/wg1/) includes an evaluation of tropospheric versus stratospheric ozone using a collage of radiative transfer model calculations. The report shows that the radiative forcing of tropospheric ozone is 10 times greater than that of stratospheric ozone, even though only $10 \%$ of the atmospheric ozone resides in the troposphere. The IPCC 2013 report (and references therein) also notes that ozone is a major surface pollutant and is important as the main source of $\mathrm{OH}$, the primary cleanser of pollutants in the troposphere. Measurements of ozone associated with deep convection are needed to characterize the extent of ozone inter-relationships with tropospheric $\mathrm{H}_{2} \mathrm{O}$ and $\mathrm{OH}$ production and to understand cloud microphysics/transport properties and the resulting influence on global and regional tropospheric ozone distributions. 
Microphysics and photochemistry can be very complex for deep convective clouds. Huntrieser et al. (2016, and references therein) combined aircraft and cloud measurements with a model to study ozone distributions and sources associated with deep convective clouds over the central US. Huntrieser et al. (2016) identified upward transport of lower tropospheric ozone and ozone precursors into the upper troposphere within thick clouds. They also showed that cloud tops overshoot the tropopause and inject high amounts of biomass burning pollutants (largely $\mathrm{CO}$ and $\mathrm{NO}_{x}$ ) and lightning-produced $\mathrm{NO}_{x}$ into the low stratosphere, while at the same time ozone-rich air from the low stratosphere is transported downward into the cloud anvil and surrounding outflow regions as a dynamical response to overshooting. Some of the Geostationary Operational Environmental Satellite (GOES) cloud tops were found to reach up to $17-18 \mathrm{~km}$ altitude for these deep convective systems. Pronounced ozone-rich stratospheric air was observed within cloud outflow regions.

The ozonesonde measurement record includes occurrences of very low to even "near-zero" ozone concentrations in the tropical upper troposphere associated with the passing of deep convective cloud systems (e.g., Kley et al., 1996; Folkins et al., 2002; Solomon et al., 2005). The very low ozone values are largely attributed to convective lifting of low concentrations of ozone from the marine boundary layer into the upper troposphere. In pollution-free oceanic regions it is not uncommon for ozone in the marine boundary layer to be only a few ppbv due to ozone net loss reactions involving hydrogen radicals $\mathrm{OH}$ and $\mathrm{HO}_{2}$ (e.g., Solomon et al., 2005, and references therein). Some studies suggest the possibility of in-cloud photochemical ozone destruction mechanisms (e.g., Zhu et al., 2001; Barth et al., 2002; Liu et al., 2006). Vömel and Diaz (2010) showed that improperly calibrated electrochemical concentration cell (ECC) ozonesondes led to a small measurement error (under-determination) and the near-zero upper troposphere ozone concentrations reported in these studies. Vömel and Diaz (2010) found that the nearzero ozone concentrations in the upper troposphere were instead about $10 \mathrm{ppbv}$ and attributed the calibration error to unaccounted variations associated with background cell currents at launch. Vömel and Diaz (2010) indicate that the studies measuring "near-zero" ozone were not wrong but rather slightly underdetermined the low ozone concentrations.

The very low ozone measurements in the tropical upper troposphere in past studies were obtained from a limited number of aircraft flights and ozonesondes at a few isolated sites in the vicinity of, but not inside, deep convective cloud systems. Measuring ozone directly inside deep convective clouds from ozonesondes and aircraft instruments remains an elusive task due to extreme meteorological conditions associated with the clouds. Ziemke et al. (2009) developed a residual "cloud slicing" method for measuring ozone volume mixing ratios (VMRs) within thick clouds by combining Aura Ozone Monitoring Instrument (OMI) and Microwave Limb
Sounder (MLS) satellite measurements. For deep convective clouds, OMI provided the tropospheric cloud-ozone measurements after subtracting co-located MLS stratospheric column ozone (SCO). Their study found large variability in the ozone concentrations in thick clouds. While very low ozone concentrations $(<10 \mathrm{ppbv})$ in the clouds were identified in the remote Indian and Pacific Ocean regions, concentrations greater than $60 \mathrm{ppbv}$ were obtained over continental landmasses including Africa. Ziemke et al. (2009) hypothesized that the ozone measured in thick clouds is largely a manifestation of ozone concentrations (from low to high amounts) present in the low troposphere/boundary layer that become transported upward by convection.

We build upon the cloud slicing work of Ziemke et al. (2009) to produce a long data record of OMI/MLS cloudozone measurements as that former study was limited to only a few months during 2005 and 2006. As with Ziemke et al. (2009), we derive ozone mixing ratios inside tropical deep convective clouds by combining Aura OMI measurements of total column ozone and cloud pressure with Aura MLS SCO. The ozone measurements represent mean ozone concentrations in the upper levels of the clouds above $550 \mathrm{hPa}$. This paper is organized as follows: Sect. 2 details the satellite measurements while Sect. 3 is an overview of cloud slicing. Section 4 discusses validation and Sects. 5-6 discuss basic characteristics and scientific interpretations of the data. Finally, Sect. 7 provides a summary.

\section{Satellite measurements}

Our study combines Aura OMI and MLS ozone measurements with OMI aerosols and cloud parameters (i.e., cloud pressures, radiative cloud fractions). OMI is a UV-vis solar backscatter spectrometer that makes daily measurements of Earth radiances and solar irradiances from 270 to $500 \mathrm{~nm}$ with spectral resolution of about $0.5 \mathrm{~nm}$ (Levelt et al., 2006). OMI scans perpendicular to the orbit path with 60 side-scan positions and provides near-global coverage of the sunlit Earth with a pixel size of $13 \mathrm{~km} \times 24 \mathrm{~km}$ at nadir. The current OMI total ozone that we use is derived using a v8.5 algorithm. Description and access to the OMI v8.5 data can be obtained from the website http://disc.sci.gsfc.nasa.gov/Aura/ data-holdings/OMI. In January 2009 a physical external optical blockage known as the "row anomaly" reduced the number of the 60 good side-scanning row measurements to about 30-40. Scan positions 21-55 are the most affected, with dependence on latitude and specific day. All of the OMI measurements that we use were properly screened to exclude all data affected by the row anomaly artifact.

OMI cloud pressures and radiative cloud fractions are derived using UV-2 radiances (Vasilkov et al., 2008). The cloud pressure from OMI is named optical centroid pressure (OCP). As shown by Vasilkov et al. (2008), the OCP at UV wavelengths lies deep inside the clouds, often by several hun- 
dred $\mathrm{hPa}$, and therefore is not a measure of true cloud top; they showed this by comparing the OMI OCP measurements with both CloudSat radar reflectivity profiles and MODIS infrared (IR) cloud pressures. The OCP effectively represents the bottom reflecting surface for the OMI retrievals in the presence of clouds. The true ozone measurement from OMI is the column amount from the top of the atmosphere down to the reflecting surface. In the presence of a cloud, the OMI algorithm places an ozone "ghost column" climatology estimate below the OCP reflecting surface to obtain total column ozone.

There are two OMI algorithms that determine the OCP. The first algorithm is based on $\mathrm{O}_{2}-\mathrm{O}_{2}$ dimer absorption (Sneep et al., 2008) and the second is based on rotationalRaman scattering (RRS) that uses spectral structures in the ratio of backscattered radiance to solar irradiance, known as the Ring effect (Joiner and Bhartia, 1995; Joiner et al., 2004, 2012; Joiner and Vasilkov, 2006). The two OMI cloud algorithms provide similar estimates of OCP for bright clouds, although there are small differences due to algorithmic and physical effects (Sneep et al., 2008). We use the RRS cloud pressure for our study although our results would be nearly identical using the $\mathrm{O}_{2}-\mathrm{O}_{2}$ cloud measurements. We refer to "cloud ozone" as the ozone column or ozone mean VMR lying between the tropopause and retrieved OCP from OMI under conditions of deep convection. We also refer to "abovecloud ozone" as the ozone column measured from OMI lying from the top of the atmosphere down to the OMI OCP. Deep convective clouds often have cloud tops at or near the tropopause. Therefore much if not most of the tropospheric ozone measured between the tropopause and OMI cloud pressure lies within the cloud itself rather than above the cloud top.

Aura MLS v4.2 profile ozone is included to measure fields of SCO. MLS SCO is used in conjunction with OMI above-cloud column ozone each day to derive mean column amounts and mean concentrations of ozone measured over deep convective clouds. The MLS ozone profiles are vertically integrated in log pressure from $0.0215 \mathrm{hPa}$ down to the tropopause to derive measurements of SCO as described by Ziemke et al. (2006, 2009). To separate stratospheric from tropospheric ozone we similarly use the WMO $2 \mathrm{~K} \mathrm{~km}^{-1}$ lapse-rate tropopause pressure definition with NCEP reanalysis temperatures. Other tropopause pressure definitions and other meteorological analyses besides NCEP could have also been used. We included the WMO definition with NCEP for both historical reasons and consistency checking relative to previous versions of our OMI/MLS tropospheric ozone products that used the same NCEP tropopause. For the low latitudes in our study we expect that there would be only minor differences in our results if we used instead a different tropopause. All MLS v4.2 retrieval quality flags (quality, status, convergence, and precision) are properly adhered to for all of our analyses. The MLS v4.2 measurements including data quality and quality flags are described in the MLS data quality document (http://mls.jpl.nasa.gov/data/ v4-2_data_quality_document.pdf). Recommended pressure levels for science applications with MLS v4.2 ozone are 0.0215 to $261 \mathrm{hPa}$. There are errors in derived SCO from MLS caused by both errors in NCEP tropopause pressure and MLS data themselves. The MLS v4.2 data quality document indicates that the vertical resolution for MLS about the tropopause is about $3 \mathrm{~km}$. This resolution is very good when compared to other current instruments for isolating stratospheric columns, particularly nadir profilers such as the NOAA Solar Backscatter Ultraviolet Spectrometer (SBUV) instrument that has vertical resolution about the tropopause $\sim 10-12 \mathrm{~km}$. Although the resolution is much better for MLS it will still affect daily SCO measurements by possibly adding errors of several Dobson units (DU). We average all daily measurements over a month which will reduce these errors if random; however, it is likely that there is a component of unresolved systematic error which will not be reduced by this averaging.

\section{Overview of cloud slicing}

We use two cloud slicing methods to measure cloud ozone from Aura OMI and MLS instruments. The first method is called "ensemble" cloud slicing that uses daily co-located measurements of cloud pressure and column ozone. This algorithm was first proposed by Ziemke et al. (2001) and combined co-located Nimbus-7 Total Ozone Mapping Spectrometer (TOMS) column ozone and Temperature Humidity Infrared Radiometer (THIR) IR cloud-top pressure. Here we combine OMI column ozone with OMI cloud pressure (i.e., OCP). An advantage of ensemble cloud ozone is that it requires only a single instrument, but weaknesses are noisiness and poor spatial resolution in the measurements. The second method is a residual cloud slicing approach (Ziemke et al., 2009) that combines OCP from OMI with residual column ozone differences between OMI and MLS. An advantage of the residual method is that it can yield measurements with high horizontal resolution. The cloud-ozone product that we generate comes from the OMI/MLS residual method. We use OMI ensemble measurements only as a consistency check for the OMI/MLS residual ozone.

A schematic diagram for the ensemble cloud slicing method is shown in Fig. 1. A region is first chosen (top of figure, $5^{\circ} \times 5^{\circ}$ region shown) with all coincident measurements (either daily or daily measurements accumulated over a month) of OMI above-cloud column ozone plotted versus OCP effective cloud pressure (bottom of figure). The OCP as noted in Sec. 2 may lie several hundred hPa below the cloud top, and the OMI algorithm places a climatological ozone ghost column below the OCP to determine total column ozone. For cloud slicing we use only the above-cloud ozone from OMI which is the true measurement. In practice, we determine the above-cloud column ozone by subtracting 


\section{"Ensemble" cloud slicing}
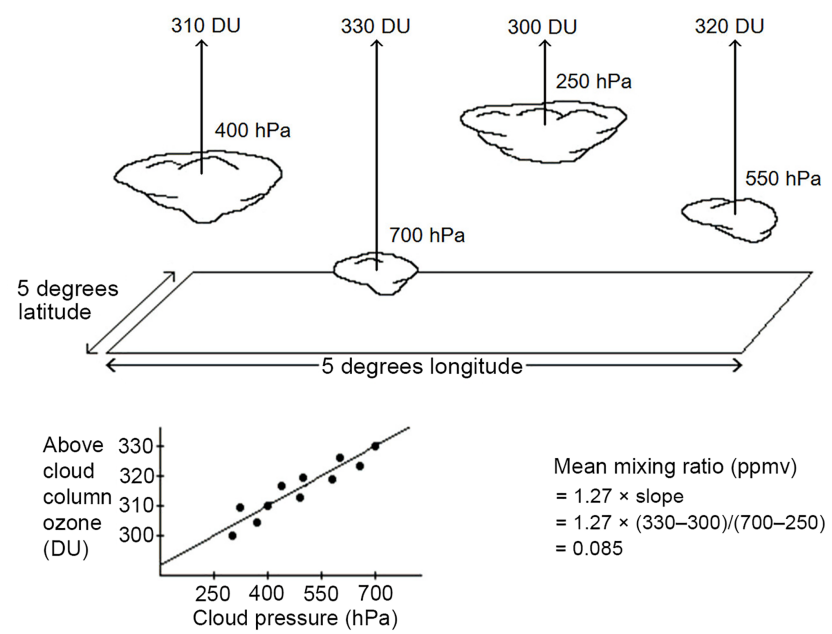

Mean mixing ratio (ppmv)

$=1.27 \times$ slope

$=1.27 \times(330-300) /(700-250)$

$=0.085$

Figure 1. A schematic diagram illustrating the ensemble cloud slicing method involving coincident measurements of above-cloud column ozone (i.e., column ozone measured from the top of the atmosphere down to cloud pressure) and cloud pressure to measure mean volume mixing ratio (see text). For deep convective cumulonimbus clouds the cloud tops are near the tropopause and so the mean volume mixing ratio is primarily a measurement of average "incloud" ozone concentration. This figure was adapted from Ziemke et al. (2001). For our study all measurements are from OMI (i.e., OMI above-cloud ozone versus OMI OCP).

the ghost column ozone from total column ozone reported in the OMI level-2 orbital datasets.

In Fig. 1 the OMI footprint scene depicted is $100 \%$ cloud filled so that the OCP deep inside the cloud represents the bottom reflecting surface for the OMI retrieval. In the more common case involving clouds, footprint scenes from OMI will not be $100 \%$ cloud filled and we account for this. What we generally use for cloud slicing in the Fig. 1 schematic is an effective scene pressure $\left(P_{\mathrm{EFF}}\right)$ in place of the OCP. $P_{\mathrm{EFF}}$ is derived from $P_{\mathrm{EFF}}=P_{\mathrm{CLOUD}} \cdot f+P_{\mathrm{SURFACE}} \cdot(1-f)$, where $P_{\text {CLOUD }}$ is the cloud OCP, $P_{\text {SURFACE }}$ is the Earth surface scene pressure, and $f$ is the OMI scene radiative cloud fraction (Joiner et al., 2009). We simplify our cloud slicing method (as was done by Ziemke et al., 2009) by using OMI measurements only when OMI reflectivity is greater than 0.80 . Choosing only OMI reflectivity scenes greater than 0.8 ensures that $f$ is equal to 1.0 , and thus $P_{\mathrm{EFF}}$ is equivalent to OCP for all of our cloud slicing measurements. We note that the deep convective clouds we incorporate generally have physical cloud tops at or near tropopause level with OCPs in the mid-upper troposphere; in such case the derived mixing ratio from cloud slicing is primarily an average measurement of ozone inside the upper levels of clouds.

Tropospheric ozone mean VMR is estimated by fitting a straight line to the data pairs of above-cloud column ozone versus OCP over the selected geographical region. This method was first described by Ziemke et al. (2001) and is summarized here. Column ozone $(\Delta \Omega)$ between two altitudes $z_{1}$ and $z_{2}$ is by definition the number of molecules per unit horizontal area and is calculated by integrating ozone number density $n$ as $\Delta \Omega=\int_{z_{1}}^{z_{2}} n \cdot \mathrm{d} z$. Using hydrostatic balance $\partial P / \partial z=-\rho g$ ( $\rho$ is mass density, $g$ is acceleration of gravity) and assuming an invariant acceleration of gravity for the troposphere this expression can be converted to $\Delta \Omega$ (in $\mathrm{DU} ; 1 \mathrm{DU}=2.69 \times 10^{20}$ molecules $\left.^{-2}\right)=C \cdot \int_{P_{1}}^{P_{2}} X \cdot d P=$ $C \cdot \bar{X} \cdot\left(P_{2}-P_{1}\right)$, where $C=0.00079 \mathrm{DU} \mathrm{hPa}^{-1} \mathrm{ppbv}^{-1}$ and $\bar{X}$ is ozone mean VMR in units ppbv. It follows that ozone mean VMR in the troposphere is $\bar{X}(\mathrm{ppbv})=1270 \cdot \Delta \Omega / \Delta P$, or in other words 1270 multiplied by the slope of the ensemble line fit. The $2 \sigma$ uncertainty for VMR in ppbv is determined by multiplying the calculated $2 \sigma$ uncertainty of the slope by 1270. An estimate for SCO can also be obtained by extrapolating the line fit to the mean tropopause pressure over the region. The above-cloud ozone at the extrapolated tropopause pressure, a direct estimate of SCO, can be compared with MLS SCO to assess how well the ensemble method separates stratospheric from tropospheric column ozone.

An example of ensemble scatter plots is shown in Fig. 2 for 5 October 2008. The left scatter plot coincides with the region of southern Africa while the right scatter plot coincides with the western Pacific. Measured ozone mixing ratio is $72 \mathrm{ppbv}$ over southern Africa and $10 \mathrm{ppbv}$ over the western Pacific. The enhanced ozone over southern Africa suggests that ozone produced from regional pollution including biomass burning, which is largest around SeptemberOctober each year in the Southern Hemisphere, reaches the upper regions of the clouds. However, the regional elevated ozone over southern Africa may be caused by other sources including lightning $\mathrm{NO}_{x}$, transport by the Walker circulation, and mixing of stratospheric air that is transported into the troposphere in response to cloud tops overshooting the tropopause (e.g., Huntrieser et al., 2016, and references therein). The low ozone VMR in the western Pacific in Fig. 2 is consistent with low values measured in the vicinity of tropical deep convection by ozonesondes (e.g., Kley et al., 1996; Folkins et al., 2002; Solomon et al., 2005; Vömel and Diaz, 2010). In principle we derive monthly cloud-ozone measurements instead of daily from the ensemble method by accumulating all co-located daily data pairs over a month.

Figure 3 illustrates the residual technique for measuring cloud ozone. This method combines OMI above-cloud column ozone and OMI OCP with MLS SCO. All of these combined measurements are daily and are co-located. For a deep convective cloud the OCP lies well inside the cloud with a cloud top often at or near the tropopause, so that much or most of measured tropospheric ozone lies inside the cloud rather than above the cloud top. The relationship (Joiner et al., 2009) to derive residual cloud-ozone VMR (units ppbv) is $\mathrm{VMR}=1270 \cdot\left[\Delta \Omega /\left(P_{\mathrm{EFF}}-P_{\mathrm{TROPOPAUSE}}\right)\right]$, where $\Delta \Omega$ 

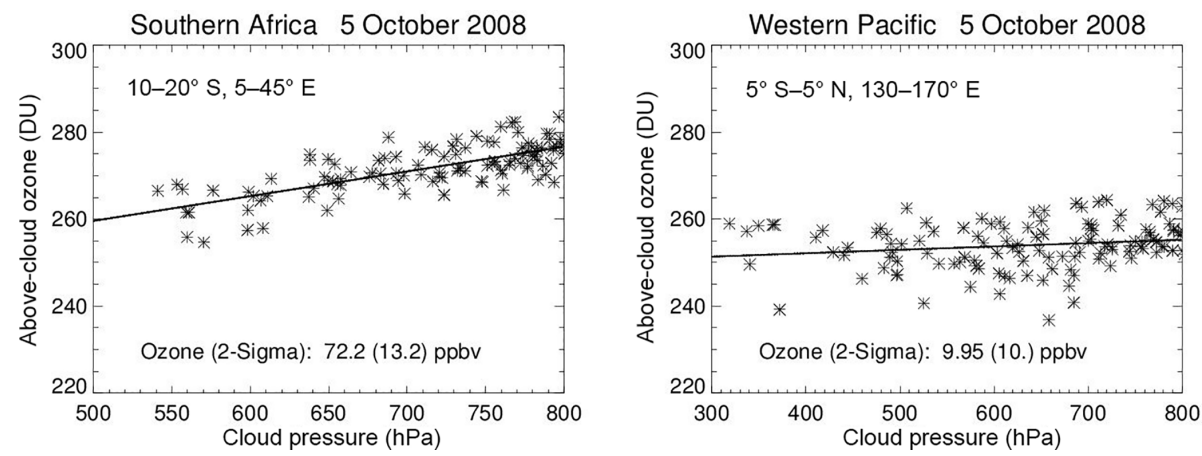

Figure 2. Examples of the ensemble cloud slicing technique using OMI measurements of above-cloud column ozone and cloud pressure (see text).

\section{Tropospheric column ozone measured over deep convective clouds}

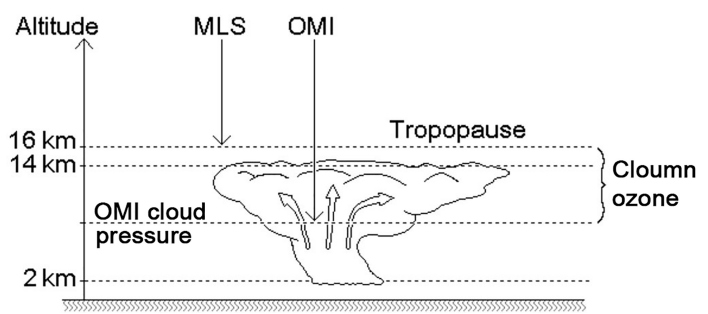

Figure 3. Schematic diagram of the OMI/MLS residual cloud slicing method. This depiction shows that deep convective clouds have OMI cloud optical centroid pressures (OCPs) lying deep inside the clouds with cloud tops often at tropopause level or very close to the tropopause. This figure was adapted from Ziemke et al. (2009).

is the difference (in DU) of OMI above-cloud column ozone minus MLS SCO, $P_{\text {TROPOPAUSE }}$ is tropopause pressure (in $\mathrm{hPa}$ ), and $P_{\mathrm{EFF}}$ is the effective scene pressure (also in $\mathrm{hPa}$ ) as discussed above. The number 1270 is the same as for the ensemble method to ensure units ppbv for VMR. As a final step, monthly-mean residual values are derived from the daily residual measurements.

We limit the latitude range for both the ensemble and residual methods to $30^{\circ} \mathrm{S}-30^{\circ} \mathrm{N}$. This was done for both approaches to reduce inherent noise due in part to strong dynamical variability of the tropopause from the tropospheric wind jets.

\section{$4 \mathrm{OMI} / \mathrm{MLS}$ residual cloud-ozone product: validation and consistency checks}

The validation of OMI/MLS residual cloud-ozone measurements is not straightforward given the paucity of in-cloud measurements from independent sources such as ozonesondes and aircraft. However, as one approach similar to Ziemke et al. (2009), we can still obtain at least a consistency check between the OMI/MLS residual cloud ozone and cloud ozone obtained from the OMI-only ensemble method.

Figure 4 compares cloud ozone from the ensemble and residual techniques for July 2015 (left panel) and October 2015 (right panel). Both of these months coincide with the intense 2014-2016 El Niño. The two panels in Fig. 4 each compare OMI/MLS residual cloud ozone (thick curves) and OMI ensemble cloud ozone (asterisks). The $5^{\circ} \mathrm{S}-10^{\circ} \mathrm{N}$ latitude band was chosen because it includes much of the Intertropical Convergence Zone with thick clouds for these months. Both the ensemble and residual cloud ozone in Fig. 4 are low to near zero in the eastern and western Pacific close to the dateline; it is conceivable that these oceanic regions coincide generally with pristine air and low concentrations of both ozone and ozone precursors in the boundary layer. In contrast, over a broad region extending from the western Pacific to Indonesia the cloud ozone from both measurements is enhanced. The increased tropospheric ozone is due to a combination of suppressed convection during El Niño and increases in biomass burning over Sumatra and Borneo due to the induced dry conditions and wildfires (e.g., Chandra et al., 1998; Logan et al., 2008). The suppressed convection during El Niño coincides with reduced upward injection of low ozone concentrations in the oceanic boundary layer compared to non-El Niño years, thus contributing to anomalous increase in cloud ozone relative to non-ENSO years. In the central Atlantic the cloud-ozone measurements are $\sim 50 \mathrm{ppbv}$ for both methods indicating higher ozone concentrations injected into the clouds from below and in general a more polluted region compared to the Pacific. In the eastern Atlantic extending to the Indian Ocean/western $\mathrm{Pa}$ cific (i.e., $\sim 60-120^{\circ}$ ) the ensemble measurements are larger than for OMI/MLS. The calculated $\pm 2 \sigma$ uncertainties for the ensemble measurements are large everywhere including this broad region and illustrate the noisy nature of the ensemble method due largely to sparseness of thick clouds. Unlike measurements for the OMI/MLS residual method, large errors in ozone for the ensemble method may originate largely 

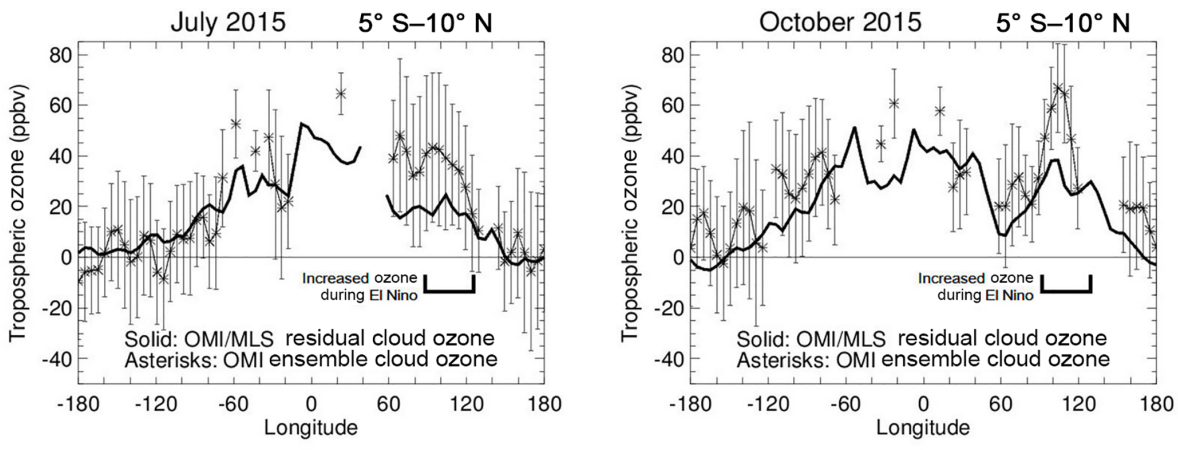

Figure 4. Comparisons of OMI/MLS (solid) and OMI ensemble (asterisks) cloud-ozone VMR for July and October 2015 with both months coinciding with the intense $2014-2016 \mathrm{El}$ Niño event. Measurements are averaged over the $5^{\circ} \mathrm{S}-10^{\circ} \mathrm{N}$ latitude band as a function of longitude (at $5^{\circ}$ increments). The ensemble measurements include calculated $\pm 2 \sigma$ uncertainties. Mean VMR for the ensemble measurements are calculated for all OCPs lying between 250 and $550 \mathrm{hPa}$ and radiative cloud fractions $>80 \%$.

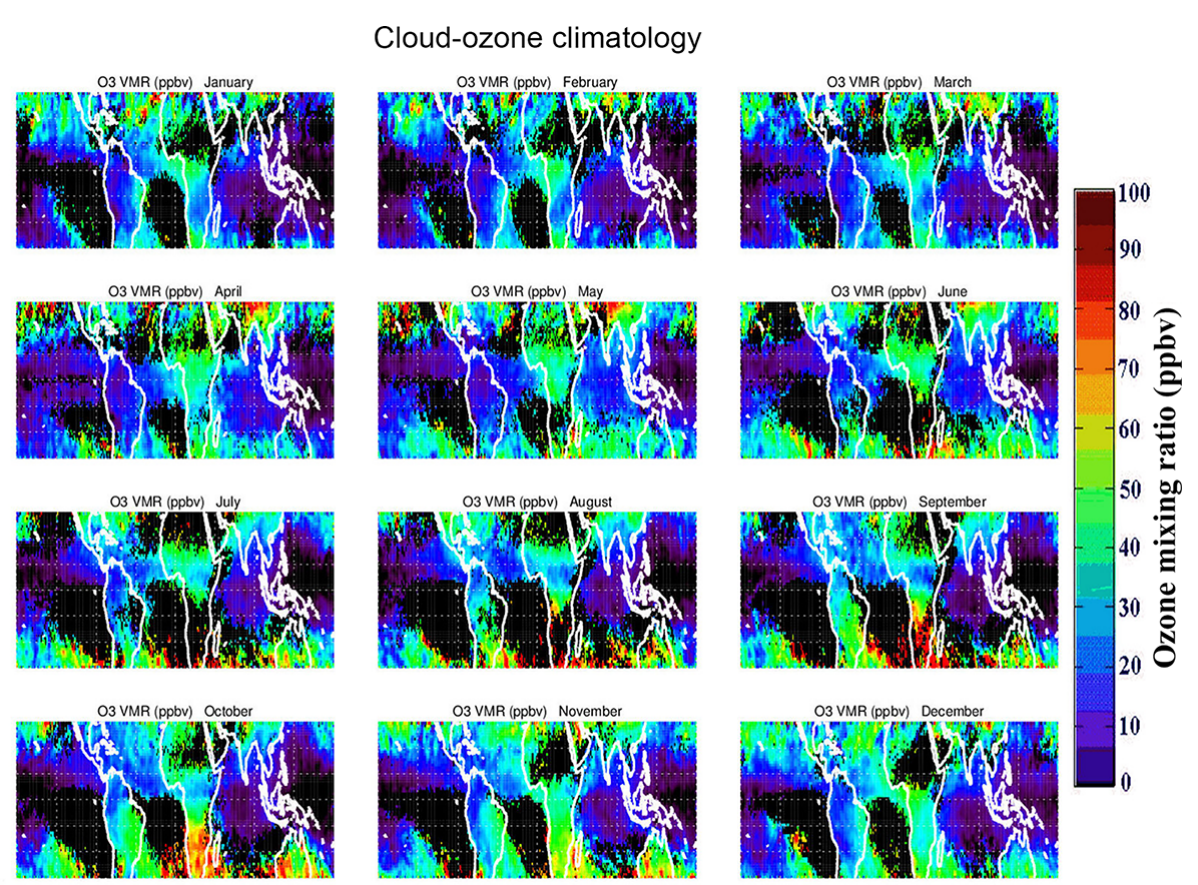

Figure 5. Monthly-mean climatology maps of OMI/MLS residual cloud ozone (units ppbv). Plotted is mean VMR representing average ozone concentration lying between the tropopause and OMI UV cloud pressure (OCP) as described in Sect. 3. The mean mixing ratio is calculated for OCPs varying between 250 and $550 \mathrm{hPa}$. Black regions indicate not enough deep convective clouds present or mostly low clouds such as marine stratus clouds with OCP lying below the $550 \mathrm{hPa}$ threshold.

from the basic assumptions of the methodology such as uniformity of both SCO and tropospheric mixing ratio throughout the chosen region. In the next two sections we discuss the OMI/MLS cloud-ozone product for basic geophysical characteristics including some science results.

\section{Monthly distributions}

Figure 5 shows monthly-mean climatology maps of OMI/MLS residual cloud ozone derived from averaging sim- ilar months over the long record. Plotted in Fig. 5 is mean VMR (units ppbv) representing average ozone concentration lying between the tropopause and OMI OCP as described in Sect. 3. In Fig. 5 the mean mixing ratio is calculated for OCPs varying between 250 and $550 \mathrm{hPa}$. We have chosen this OCP pressure band to help isolate optically thick clouds with cloud tops generally at or near tropopause level (e.g., see Fig. 12 of Vasilkov et al., 2008). The black regions in Fig. 5 indicate that not enough deep convective clouds are present and/or mostly clouds such as low-marine stratus clouds with OCP lying below the $550 \mathrm{hPa}$ threshold. 


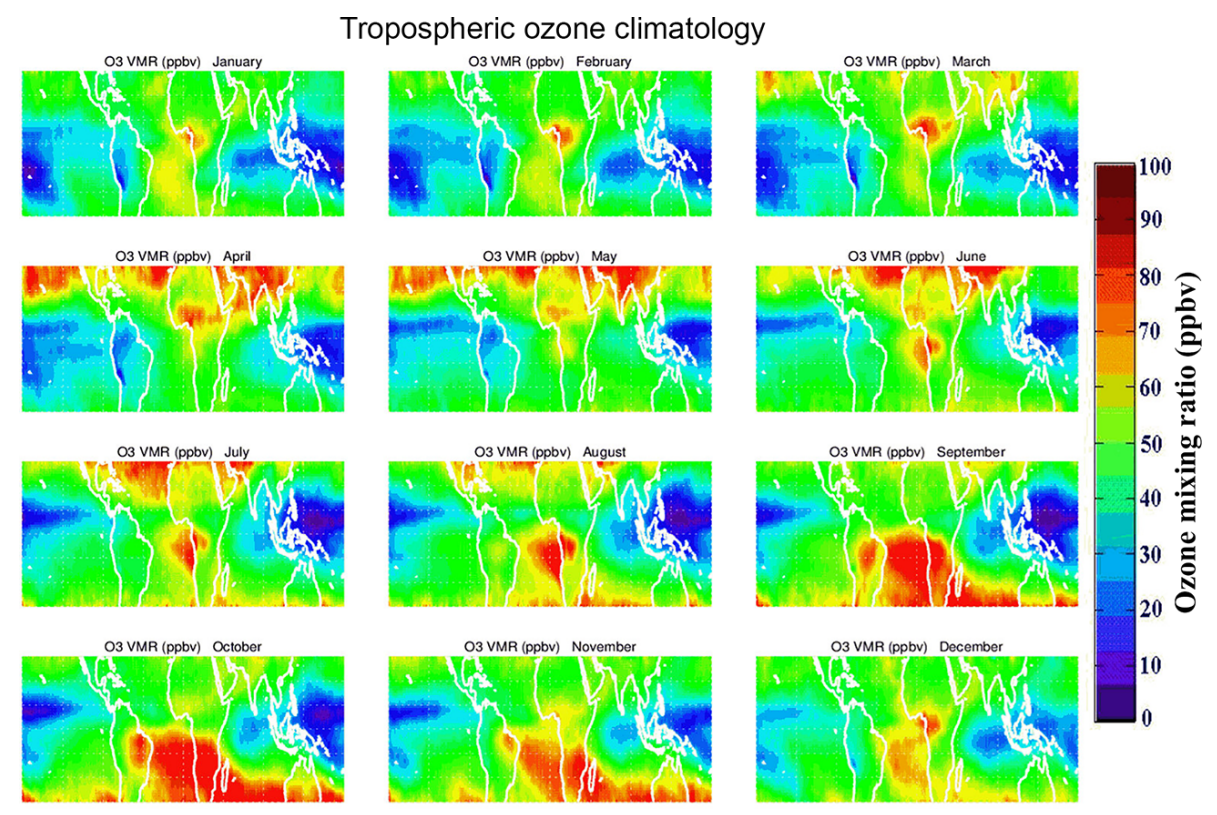

Figure 6. Similar to Fig. 5, but instead plotting monthly-mean climatology maps of OMI/MLS VMR (units ppbv) for OMI near clear-sky scenes (i.e., radiative cloud fractions less than $30 \%$ ).

The distributions in Fig. 5 illustrate the large regional and temporal variability present in cloud ozone. In the remote Pacific and Indian Ocean regions the values of cloud ozone are small at $\sim 10$ ppbv or less. High values reaching $70-80 \mathrm{ppbv}$ are measured for landmass regions of India/east Asia, southern Africa and South America, and Australia. The high ozone is indicative of a more polluted lower troposphere/boundary layer. There are also some ozone values $\sim 40-50$ ppbv over both the Atlantic and Pacific Ocean regions in higher latitudes which are large yet still small compared to the noted high values over landmasses. Understanding variations in the ozone concentrations over oceanic thick clouds is a work in progress that combines these OMI/MLS measurements with a free-running chemistry-climate model (Strode et al., 2017).

Figure 6 shows climatology maps similar to Fig. 5 but instead for "background" ozone mean VMR. The background ozone is derived using only OMI near clear-sky scenes for column ozone where radiative cloud fractions are less than $30 \%$. In Fig. 6 the east-west tropical wave-one pattern in tropospheric ozone (Fishman et al., 1990) is easily discerned year round with high values $\sim 60-80 \mathrm{ppbv}$ in the Atlantic and low values $\sim 20 \mathrm{ppbv}$ in the eastern and western Pacific. According to Sauvage et al. (2007) using the GEOSChem chemical transport model (CTM) the main source of tropospheric ozone in the tropical Atlantic on annual-mean basis comes from lightning $\mathrm{NO}_{x}$ with smaller contributions from biomass burning, soils, and fossil fuels (by factors varying 4-6). Their CTM also indicated that stratospheretroposphere exchange accounts for less than about $5 \%$ of tropospheric ozone burden in the tropical Atlantic and that most of the effects from $\mathrm{NO}_{x}$ came from Africa. In the southern hemispheric subtropics in Fig. 6 there is a buildup of high ozone in August-November along all longitudes. Although the southern hemispheric Atlantic maximum in Fig. 6 occurs in every month year round, this feature also exhibits substantial interannual variability (IAV). Liu et al. (2017) combined GEOS-5 assimilated OMI/MLS ozone and Goddard Modeling Initiative (GMI) CTM simulations to quantify the causes of the IAV of tropospheric ozone over four subregions of the southern hemispheric tropospheric ozone maximum. They found that the strong influence of emission on ozone IAV is largely confined to the south Atlantic region in September at and below $\sim 430 \mathrm{hPa}$. In the middle and upper troposphere, the IAV of the stratospheric ozone contribution is the most important factor driving the IAV of ozone over two selected tropical regions: the tropical south Atlantic and tropical southeastern Pacific, especially during the austral winter season.

\section{Time series}

With about 12 years of measurements from OMI/MLS we can analyze variability from monthly to decadal timescales of the OMI/MLS residual cloud ozone and compare these changes with background ozone. In Fig. 7 we show eight selected regions of interest for background ozone (top) and cloud ozone (bottom) for October 2006. For these eight selected regions we have averaged cloud ozone and background ozone each month to generate long-record time series starting October 2004. 


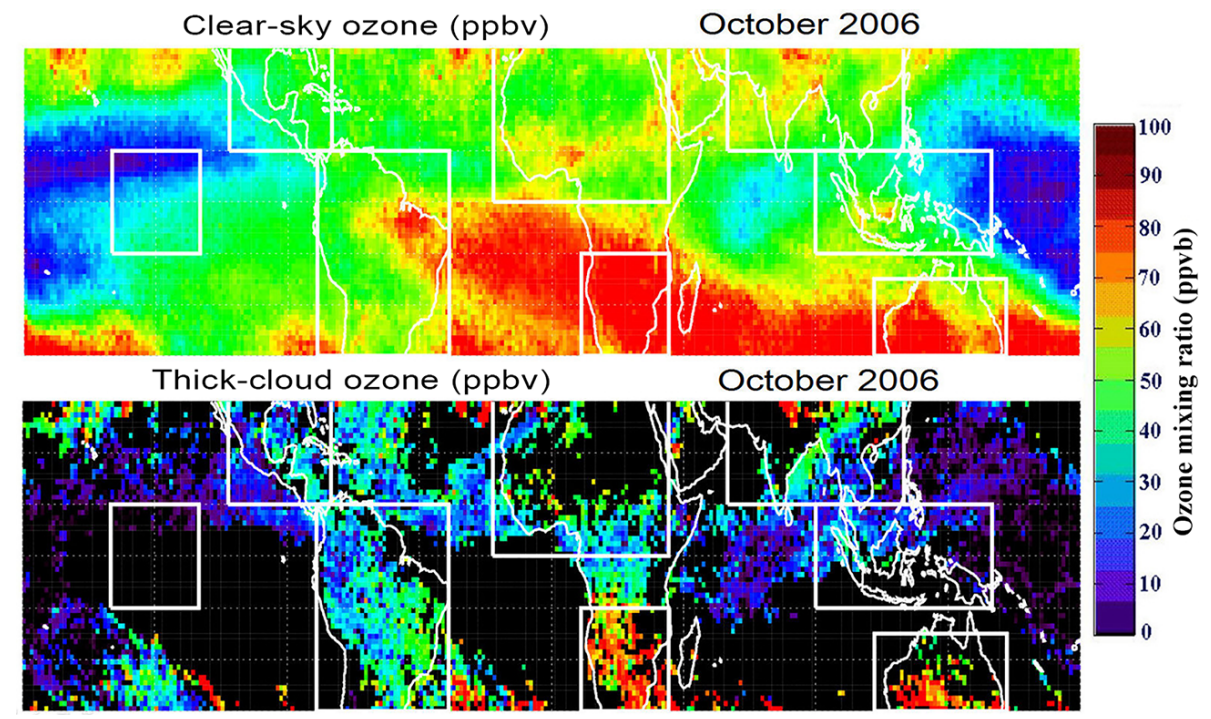

Figure 7. Top: background (near clear-sky) tropospheric ozone in units ppbv for October 2006. Shown as white rectangles are eight selected regions of interest where measurements are averaged each month to generate long-record time series for October 2004-April 2016. Bottom: same as top but instead for cloud ozone.
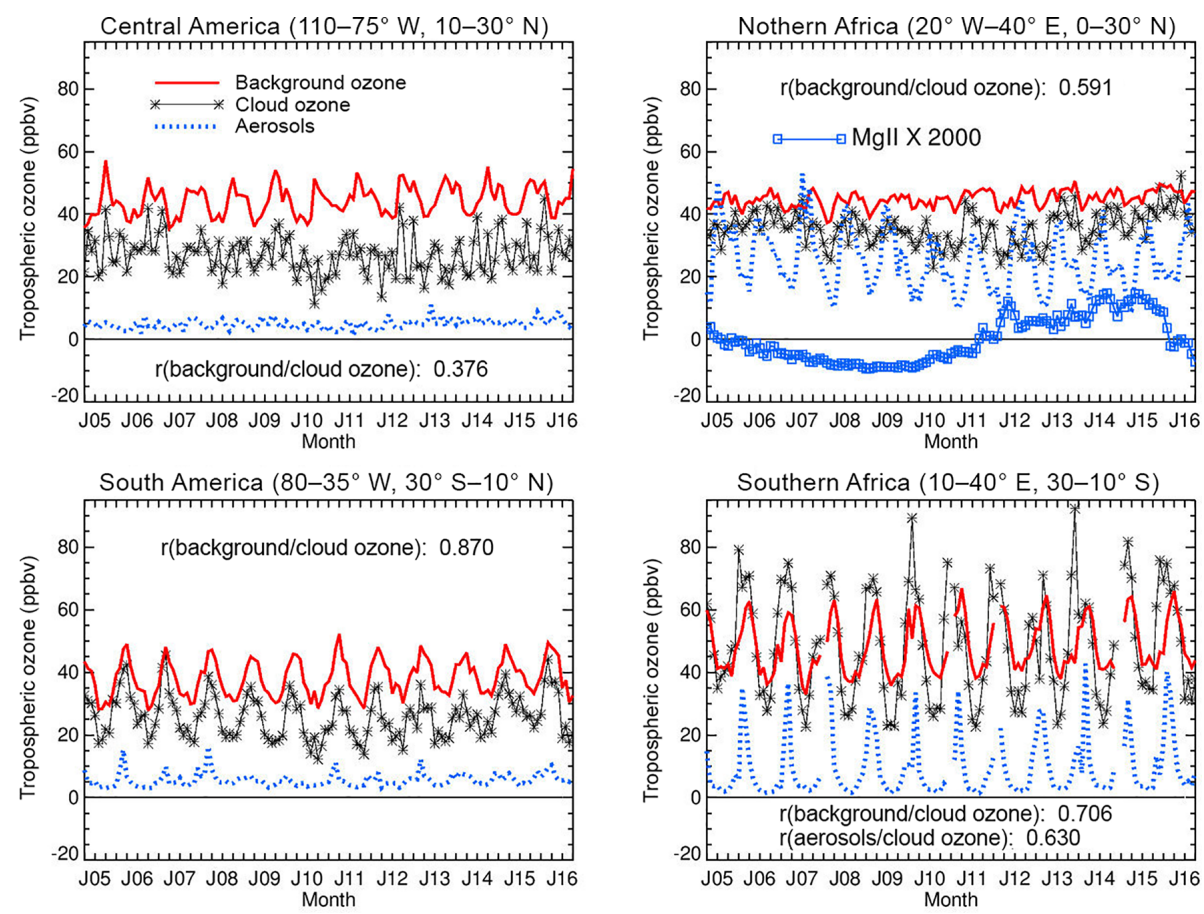

Figure 8. Monthly time series of background ozone (thick solid red curves) and cloud ozone (thin black curves with asterisks) for the regions of Central America, South America, northern Africa, and southern Africa in Fig. 7. All ozone units are ppbv. Also shown for each of these landmass regions is the OMI monthly aerosol index time series (dotted blue curves, no units) which was rescaled (i.e., multiplied by 60) for plotting. Included for the northern Africa region is the solar Mg II index (SI units) that has been rescaled for plotting (i.e., time average removed and then multiplied by 2000). The correlation between background ozone and cloud ozone is indicated in each panel. Also included for southern Africa is correlation between aerosol index and cloud ozone.

Time series of the monthly background ozone and cloud ozone for the eight regions are plotted in Figs. 8 and 9. In all of these eight panels the background ozone is plotted as the thick solid curve while cloud ozone is the thin curve with asterisks. Also plotted for the six landmass regions in Figs. 8-9 are time series of the OMI aerosol index (dotted blue curves). 

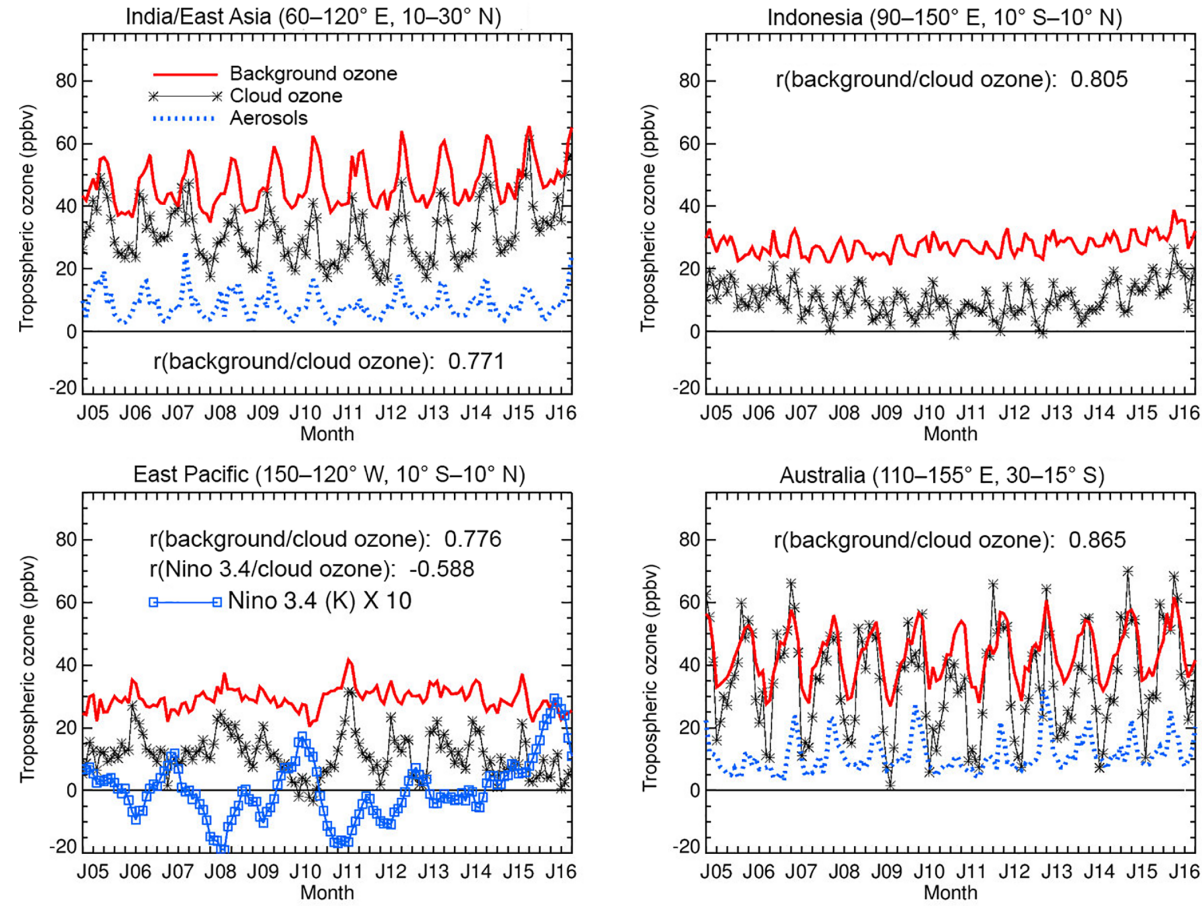

Figure 9. Similar to Fig. 8, but instead for the regions of India/east Asia, Indonesia, eastern Pacific, and Australia. Aerosol index time series (dotted) for the landmass regions is again shown. Also included for the eastern Pacific (lower left panel) is the Niño 3.4 index (blue squares, units K) and its correlation with cloud ozone. The Niño 3.4 index was rescaled (multiplied by 10) for plotting with ozone time series.

In Fig. 8 for northern Africa we include a line plot of the solar Mg II UV index (blue squares) for comparing decadal changes in ozone in all eight panels in Figs. 8-9 with the 11-year solar cycle. In the eastern Pacific region in Fig. 9 the Niño 3.4 index (blue squares) is also plotted to demonstrate the dependence of cloud-ozone variability from ENSO in this particular region. All background ozone and aerosol time series in Figs. 8-9 were flagged missing wherever (at $1^{\circ} \times 1.25^{\circ}$ gridding) and whenever (monthly means) corresponding measurements for cloud ozone were missing.

Figure 8 compares ozone time series for the following four regions: Central America, South America, northern Africa, and southern Africa. In each panel the correlation between cloud ozone and background ozone is shown. In addition the correlation between cloud ozone and aerosols is also included for southern Africa. With the exception of the southern Africa region, the background ozone is larger than cloud ozone by $\sim 10-20$ ppbv year round. For southern Africa the cloud ozone each year in summer months exceeds background ozone by $\sim 5-10 \mathrm{ppbv}$ on average. The annual cycle for cloud ozone with southern Africa does not appear to be in phase with background ozone, reaching its annual maximum about 1-2 months earlier. The aerosol index time series in Fig. 8 for southern Africa represents seasonality of biomass burning in the region and it also peaks $1-2$ months prior to maximum background ozone; the correlation between cloud ozone and aerosols shown in this panel for southern Africa is about 0.63 . Sporadic thick clouds in the presence of tropospheric ozone from biomass burning via nearby regions may explain the higher ozone values and 1-2-month phase lead for cloud ozone relative to background ozone.

With Central America in Fig. 8 (upper left panel) some of the month-to-month maxima and minima for cloud ozone coincide with relative maxima and minima in background ozone on intraseasonal timescale. The Central America region including the Caribbean Sea/Gulf of Mexico and extending into the tropical north Atlantic is well documented for intraseasonal variability in winds and cyclonic development (e.g., Park and Schubert, 1993; Maloney and Hartmann, 2000; Mo, 2000; Foltz and McPhaden, 2004, 2005). Seasonal variability in Fig. 8 for both background ozone and cloud ozone is most pronounced for southern Africa and weakest for northern Africa.

For decadal timescales, the background ozone in all four regions in Fig. 8 is mostly invariant while cloud ozone shows small decreases toward the middle of the record followed by small increases afterward. Comparing with the $\mathrm{Mg}$ II index in the upper right panel, this decadal variability for cloud ozone does not appear to be directly related to the 11-year cycle in solar UV, which has minima centered around year 2009 and also at the end of the record.

Figure 9 shows time series for four additional regions: India/east Asia, Indonesia, eastern Pacific, and Australia. With the exception of Australia (lower right panel), the 

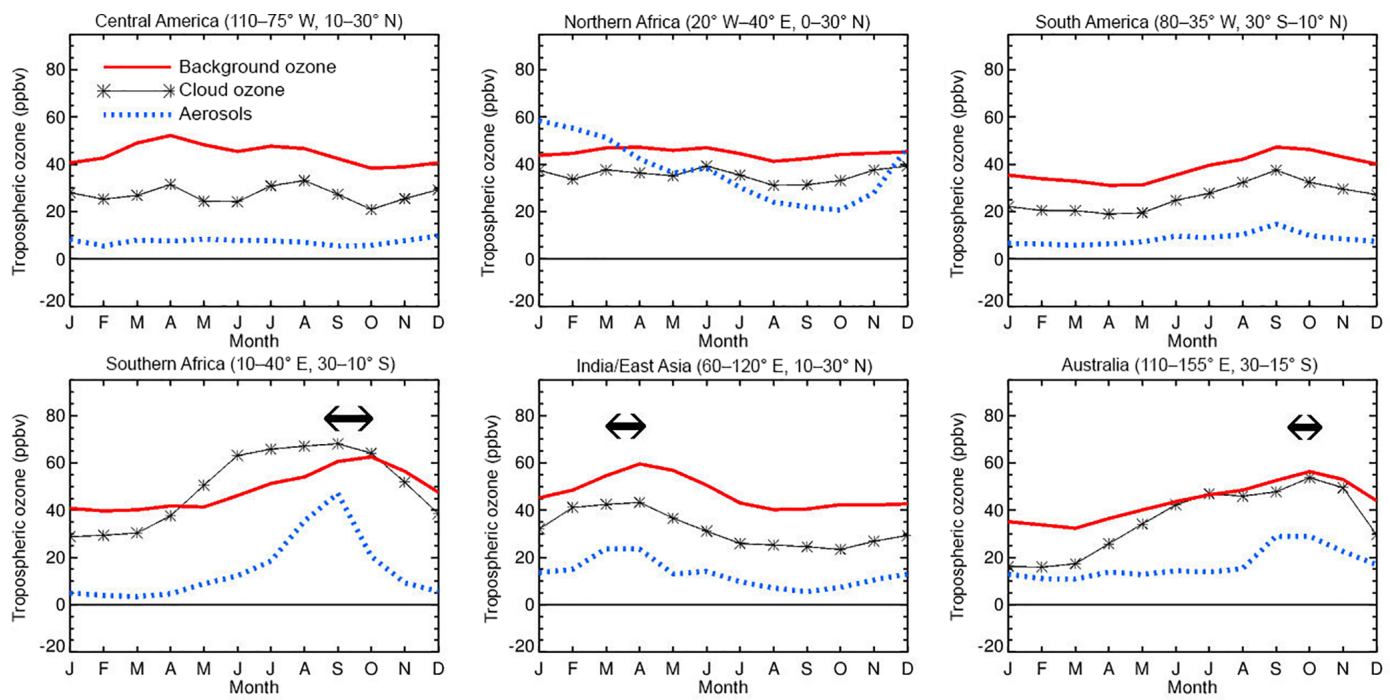

Figure 10. Twelve-month climatology time series for the six continental landmass regions plotted in Figs. 8 and 9 using the same color scheme. Shown here are background ozone (solid red curves), cloud ozone (asterisks), and aerosol index (dotted blue curves). The OMI aerosol index has been rescaled (i.e., multiplied by 60) for plotting. Approximate phase shifts between background ozone and aerosol index time series are shown with dark arrows.

background ozone is larger than cloud ozone by $\sim 10$ 20 ppbv year round. The cloud ozone and background ozone for Australia are comparable during July-November months (i.e., similar to southern Africa in Fig. 8). For Indonesia and the eastern Pacific the cloud ozone is sometimes very low to even near zero, which is indicative of clean air with low concentrations of boundary-layer ozone and ozone precursors. Indonesia in Fig. 9 indicates intraseasonal variability for both cloud ozone and background ozone. In this western pacific region the main source of intraseasonal variability of tropospheric ozone is the 1-2-month Madden-Julian oscillation (e.g., Ziemke et al., 2015, and references therein).

Decadal changes of cloud ozone in Fig. 9, with the exception of the eastern Pacific, appear again to have relative minima around the middle of the long record and no clear connection with the 11-year solar cycle in UV. Included in the panel for the eastern Pacific region is the Niño 3.4 index time series (squares along bottom), which was rescaled for plotting with the ozone. For the eastern Pacific it is clear that there is dominant IAV related to ENSO events with associated changes in convection/sea surface temperature (SST) (i.e., opposite correlation between them is indicated). For this eastern Pacific region the cloud ozone is greatest during La Niña (suppressed convection in the region) and lowest during El Niño (enhanced convection in the region).

It is difficult to discern timing of the seasonal minima and maxima of the aerosol and ozone time series in Figs. 8-9. For this reason we have included Fig. 10, which compares 12-month climatologies of background ozone, cloud ozone, and aerosol index time series for the six landmass regions plotted in Figs. 8-9. One main conclusion from Fig. 10 is that seasonal maxima of background ozone for the landmass regions of southern Africa, India/east Asia, and Australia all tend to occur about 1 month after maxima in aerosols. For southern Africa and India/east Asia the aerosol maximum occurs around the same month as the maximum in cloud ozone. These phase shifts suggest that biomass burning during the mostly dry season has an important impact on the seasonal cycles of tropospheric ozone including India where monsoon does not generally begin until late May or early June. It is beyond the scope of our study to explain the relative amplitude differences and phase shifts between background and cloud-ozone measurements. Explaining these characteristics will require a future investigation using either a CTM or a chemistry-climate model with an appropriate convection scheme.

\section{Summary}

We applied a residual technique to derive a data record (October 2004-recent) of tropospheric ozone mixing ratios inside deep convective clouds in the tropics and subtropics from OMI/MLS satellite measurements. This residual technique makes use of the cloud OCP obtained from the effects of RRS in the OMI UV spectra. Solar UV penetrates deep into thick clouds, often by several hundred $\mathrm{hPa}$. In addition, deep convective clouds have high cloud tops often near or at tropopause level. As a result the OMI/MLS cloud-ozone measurements are largely indicative of ozone concentrations lying inside the clouds.

The OMI/MLS residual cloud ozone was compared with OMI/MLS near clear-sky ozone (denoted "background" ozone), indicating substantially lower concentrations (by 
$\sim 10-20$ ppbv) for cloud ozone year round, with the exception of southern Africa and Australia during July-November months. For both southern Africa and Australia the seasonal maxima of cloud ozone were found to exceed seasonal maxima of background ozone by about 5-10 ppbv. For both southern Africa and India/east Asia the seasonal maxima for both OMI aerosols and cloud ozone occur about 1-2 months earlier than for background ozone. The analyses imply a cause and effect relation between boundary-layer pollution and elevated ozone inside thick clouds over landmass regions including southern Africa and India/east Asia.

While large cloud-ozone concentrations $\sim 60 \mathrm{ppbv}$ or greater occur over landmass regions of India/east Asia, South America, southern Africa, and Australia, very low cloud ozone is persistent over the Indian Ocean and eastern/western Pacific Ocean with values $\sim 10$ ppbv or smaller. A low concentration of cloud ozone measured in these oceanic regions is indicative of generally pristine air with small amounts of ozone and ozone precursors in the marine boundary layer/low troposphere.

There is indication of intraseasonal variability in cloud ozone over the eastern and western Pacific Ocean regions and also over Central America. In the western Pacific the intraseasonal variability originates largely from the 1-2-month Madden-Julian oscillation. In the eastern Pacific the largest variability is interannual and originates from ENSO and associated changes in SST/convection. In the eastern Pacific the highest cloud ozone occurs during La Niña (suppressed convection over the region) with lowest cloud ozone during El Niño (enhanced convection).

Understanding changes in convection versus changes in emissions and how they relate to the variabilities in measured cloud ozone is beyond the scope of our study. A photochemical model involving deep convective clouds would be necessary to study the variability for cloud ozone from monthly to decadal timescale. The current work of Strode et al. (2017) combines these OMI/MLS measurements with a chemistryclimate model to evaluate properties of cloudy versus clearsky background ozone.

Data availability. The monthly gridded cloud ozone and background ozone data can be obtained via anonymous ftp from the following:

- ftp://jwocky.gsfc.nasa.gov (last access: 24 October 2017)

- Name: anonymous

- Password: (your email address)

- cd pub/ccd/data_monthly

- get vmr_30s_to_30n_oct04_to_apr16.sav

Competing interests. The authors declare that they have no conflict of interest.
Acknowledgements. The authors thank the Aura MLS and OMI instrument and algorithm teams for the extensive satellite measurements used in this study. OMI is a Dutch-Finnish contribution to the Aura mission. Funding for this research was provided in part by NASA NNH14ZDA001N-DSCOVR.

Edited by: Mark Weber

Reviewed by: two anonymous referees

\section{References}

Barth, M. C., Hess, P. G., and Madronich, S.: Effect of marine boundary layer clouds on tropospheric chemistry as analyzed in a regional chemistry transport model, J. Geophys. Res., 107, 4126, https://doi.org/10.1029/2001JD000468, 2002.

Chandra, S., Ziemke, J. R., Min, W., and Read, W. G.: Effects of 1997-1998 El Niño on tropospheric ozone and water vapor, Geophys. Res. Lett., 25, 3867-3870, 1998.

Fishman, J., Watson, C. E., Larsen, J. C., and Logan, J. A.: Distribution of tropospheric ozone determined from satellite data, J. Geophys. Res., 95, 3599-3617, 1990.

Folkins, I., Braun, C., Thompson, A. M., and Witte, J.: Tropical ozone as an indicator of deep convection, J. Geophys. Res., 107, ACH 13-1-ACH 13-10, https://doi.org/10.1029/2001JD001178, 2002.

Foltz, G. R. and McPhaden, M. J.: The 30-70 day oscillations in the tropical Atlantic, Geophys. Res. Lett., 31, L15205, https://doi.org/10.1029/2004GL020023, 2004.

Foltz, G. R. and McPhaden, M. J.: Mixed layer heat balance on intra-seasonal time scales in the northwestern tropical Atlantic Ocean, J. Climate, 18, 4168-4187, 2005.

Hartmann, D. L., Klein Tank, A. M. G., Rusticucci, M., Alexander, L. V., Brönnimann, S., Charabi, Y., Dentener, F. J., Dlugokencky, E. J., Easterling, D. R., Kaplan, A., Soden, B. J., Thorne, P. W., Wild, M., and Zhai, P. M.: Observations: Atmosphere and Surface, in: Climate Change 2013: The Physical Science Basis, Contribution of Working Group I to the Fifth Assessment Report of the Intergovernmental Panel on Climate Change, edited by: Stocker, T. F., Qin, D., Plattner, G.-K., Tignor, M., Allen, S. K., Boschung, J., Nauels, A., Xia, Y., Bex, V., and Midgley, P. M., Cambridge University Press, Cambridge, United Kingdom and New York, NY, USA, 2014.

Huntrieser, H., Lichtenstern, M., Scheibe, M., Aufmhoff, H., Schlager, H., Pucik, T., Minikin, A., Weinzierl, B., Heimerl, K., Fütterer, D., Rappenglück, B., Ackermann, L., Pickering, K. E., Cummings, K. A., Biggerstaff, M. I., Betten, D. P., Honomichl, S., and Barth, M. C.: On the origin of pronounced $\mathrm{O}_{3}$ gradients in the thunderstorm outflow region during DC3, J. Geophys. Res. Atmos., 121, 6600-6637, https://doi.org/10.1002/2015JD024279, 2016.

Joiner, J. and Bhartia, P. K.: The determination of cloud pressures from rotational-Raman scattering in satellite backscatter ultraviolet measurements, J. Geophys. Res., 100, 23019-23026, 1995.

Joiner, J. and Vasilkov, A. P.: First results from the OMI rotational Raman scattering cloud pressure algorithm, IEEE T. Geosci. Remote Sens., 44, 1272-1282, 2006.

Joiner, J., Vasilkov, A. P., Flittner, D. E., Gleason, J. F., and Bhartia, P. K.: Retrieval of cloud pressure and oceanic chlorophyll content 
using Raman scattering in GOME ultraviolet spectra, J. Geophys. Res., 109, D01109, https://doi.org/10.1029/2003JD003698, 2004.

Joiner, J., Schoeberl, M. R., Vasilkov, A. P., Oreopoulos, L., Platnick, S., Livesey, N. J., and Levelt, P. F.: Accurate satellitederived estimates of the tropospheric ozone impact on the global radiation budget, Atmos. Chem. Phys., 9, 4447-4465, https://doi.org/10.5194/acp-9-4447-2009, 2009.

Joiner, J., Vasilkov, A. P., Gupta, P., Bhartia, P. K., Veefkind, P., Sneep, M., de Haan, J., Polonsky, I., and Spurr, R.: Fast simulators for satellite cloud optical centroid pressure retrievals; evaluation of OMI cloud retrievals, Atmos. Meas. Tech., 5, 529-545, https://doi.org/10.5194/amt-5-529-2012, 2012.

Kley, D., Crutzen, P. J., Smit, H. G. J., Vömel, H., Oltmans, S. J., Grassl, H., and Ramanathan, V.: Observations of near-zero ozone concentrations over the convective Pacific: Effects on air chemistry, Science, 274, 230-233, 1996.

Levelt, P. F., van den Oord, G. H. J., Dobber, M. R., Malkki, A., Visser, H., de Vries, J., Stammes, P., and Saari, H.: The Ozone Monitoring Instrument, IEEE T. Geophys. Remote Sens., 44, 1093-1101, 2006.

Liu, H. Y., Crawford, J. H., Pierce, R. B., Norris, P., Platnick, S. E., Chen, G., Logan, J. A., Yantosca, R. M., Evans, M. J., Kittaka, C., Feng, Y., and Tie, X.: Radiative effect of clouds on tropospheric chemistry in a global three-dimensional chemical transport model, J. Geophys. Res., 111, D20303, https://doi.org/10.1029/2005JD006403, 2006.

Liu, J., Rodriguez, J. M., Steenrod, S. D., Douglass, A. R., Logan, J. A., Olsen, M. A., Wargan, K., and Ziemke, J. R.: Causes of interannual variability over the southern hemispheric tropospheric ozone maximum, Atmos. Chem. Phys., 17, 3279-3299, https://doi.org/10.5194/acp-17-3279-2017, 2017.

Logan, J. A., Megretskaia, I., Nassar, R., Murray, L. T., Zhang, L., Bowman, K. W., Worden, H. M., and Luo, M.: Effects of the 2006 El Niño on tropospheric composition as revealed by data from the Tropospheric Emission Spectrometer (TES), Geophys. Res. Lett., 35, L03816, https://doi.org/10.1029/2007GL031698, 2008.

Maloney, E. D. and Hartmann, D. L.: Modulation of hurricane activity in the Gulf of Mexico by the Madden-Julian Oscillation, Science, 287, 2002-2004, 2000.

Mo, K. C.: The association between intra-seasonal oscillations and tropical storms in the Atlantic Basin, Mon. Weather Rev., 128, 4097-4107, 2000.

Park, C.-K. and Schubert, S. D.: Remotely forced intra-seasonal oscillations over the tropical Atlantic, J. Atmos. Sci., 50, 89-103, 1993.
Sauvage, B., Martin, R. V., van Donkelaar, A., and Ziemke, J. R.: Quantification of the factors controlling tropical tropospheric ozone and the South Atlantic maximum, J. Geophys. Res., 112, D11309, https://doi.org/10.1029/2006JD008008, 2007.

Solomon, S., Thompson, D. W. J., Portmann, R. W., Oltmans, S. J., and Thompson, A. M.: On the distribution of and variability of ozone in the tropical upper troposphere: Implications for tropical deep convection and chemical-dynamical coupling, Geophys. Res., Lett., 32, L23813, https://doi.org/10.1029/2005GL024323, 2005.

Sneep, M., De Haan, J., Stammes, P., Wang, P., Vanbauce, C., Joiner, J., Vasilkov, A., and Levelt, P.: Three way comparison between OMI/Aura and POLDER/PARASOL cloud pressure products, J. Geophys. Res., 113, D15S23, https://doi.org/10.1029/2007JD008694, 2008.

Strode, S. A., Douglass, A. R., Ziemke, J. R., Manyin, M., Nielsen, J. E., and Oman, L. D.: Analysis of ozone in clear versus cloudy conditions, J. Geophys. Res., in press, 2017.

Vasilkov, A., Joiner, J., Spurr, R., Bhartia, P. K., Levelt, P., and Stephens, G.: Evaluation of the OMI cloud pressures derived from rotational Raman scattering by comparisons with other satellite data and radiative transfer simulations, J. Geophys. Res., 113, D15S19, https://doi.org/10.1029/2007JD008689, 2008.

Vömel, H. and Diaz, K.: Ozone sonde cell current measurements and implications for observations of near-zero ozone concentrations in the tropical upper troposphere, Atmos. Meas. Tech., 3, 495-505, https://doi.org/10.5194/amt-3-495-2010, 2010.

Zhu, B., Xiao, H., Huang, M., and Li, Z.: Numerical study of cloud effects on tropospheric ozone, Water Air Soil Poll., 129, 199216, 2001.

Ziemke, J. R., Chandra, S., and Bhartia, P. K.: "Cloud slicing": A new technique to derive upper tropospheric ozone from satellite measurements, J. Geophys. Res., 106, 9853-9867, 2001.

Ziemke, J. R., Chandra, S., Duncan, B. N., Froidevaux, L., Bhartia, P. K., Levelt, P. F., and Waters, J. W.: Tropospheric ozone determined from Aura OMI and MLS: Evaluation of measurements and comparison with the Global Modeling Initiative's Chemical Transport Model, J. Geophys. Res., 111, D19303, https://doi.org/10.1029/2006JD007089, 2006.

Ziemke, J. R., Joiner, J., Chandra, S., Bhartia, P. K., Vasilkov, A., Haffner, D. P., Yang, K., Schoeberl, M. R., Froidevaux, L., and Levelt, P. F.: Ozone mixing ratios inside tropical deep convective clouds from OMI satellite measurements, Atmos. Chem. Phys. 9, 573-583, https://doi.org/10.5194/acp-9-573-2009, 2009.

Ziemke, J. R., Douglass, A. R., Oman, L. D., Strahan, S. E., and Duncan, B. N.: Tropospheric ozone variability in the tropics from ENSO to MJO and shorter timescales, Atmos. Chem. Phys., 15, 8037-8049, https://doi.org/10.5194/acp-15-8037-2015, 2015. 